\title{
Pneumocephalus and Pneumorrhachis due to a Subarachnoid Pleural Fistula That Developed after Thoracic Spine Surgery
}

\author{
Gun-Sang Lee, Myung-Ki Lee, Woo-Jae Kim, Ho-Sang Kim, Jeong-Ho Kim, Yun-Suk Kim \\ Department of Neurosurgery, Maryknoll Medical Center, Busan, Korea
}

Development of a communication between the spinal subarachnoid space and the pleural space after thoracic spine surgery is uncommon. Subarachnoid pleural fistula (SAPF), a distressing condition, involves cerebrospinal fluid leakage. Here we report an unusual case of SAPF, occurring after thoracic spine surgery, that was further complicated by pneumocephalus and pneumorrhachis postthoracentesis, which was performed for unilateral pleural effusion.

Key Words: Pneumorrhachis $\cdot$ Surgery $\cdot$ Pneumocephalus

\section{INTRODUCTION}

Pneumorrhachis and pneumocephalus due to a fistula are rare. Another rare condition is a communication between the spinal subarachnoid space and pleural space after thoracic spine surgery. Pneumocephalus may manifest as severe headache $e^{4,5,79)}$ and acute neurologic changes that mimic brain metastasis, seizure, or stroke. However, the physiology and management of pneumocephalus are not widely recognized. Here we report an unusual case of subarachnoid pleural fistula (SAPF), occurring after thoracic spine surgery, that was further complicated by pneumocephalus and pneumorrhachis postthoracentesis, which was performed for unilateral pleural effusion.

\section{CASE REPORT}

A 47-year-old woman presented with severe headache, nausea, and vomiting. A known case of T1-T8 posterior longitudinal ligament ossification, she had undergone decompressive laminectomy at T1-T2 and T8, 7 years ago and posterior decompression at T11-L2, 2 years ago at another hospital. At that time, dural tear was unknown. She was in her usual state of health until 10 days before admission to the respiratory department for violent coughing and sputum. A chest radiograph and computed tomography (CT) scan (Fig. 1) revealed left-sided

- Received: November 27, 2015 • Revised: August 2, 2016

- Accepted: August 3, 2016

Corresponding Author: Gun-Sang Lee

Department of Neurosurgery, Maryknoll Medical Center, 121,

Junggu-ro, Jung-gu, Busan 48972, Korea

Tel: +82-51-461-2456, Fax: +82-51-465-7470

E-mail: mkhns2012@gmail.com

$\otimes$ This is an open access article distributed under the terms of the Creative Commons Attribution Non-Commercial License (http://creativecommons.org/licenses/by-nc/4.0/) which permits unrestricted non-commercial use, distribution, and reproduction in any medium, provided the original work is properly cited. pleural effusion. Thoracentesis was performed, following which she developed sudden headache, nausea, and vomiting. Brain CT scan revealed pneumocephalus, with air in the ventricle and the subarachnoid space (Fig. 2). A chest CT showed a communication between the pleural cavity and the $\mathrm{T} 2$ spinal canal with intraspinal air (Fig. 3). The precise location of the SAPF was identified on a CT myelogram with iohexol. The patient refused surgical repair of the SAPF; therefore, conservative ma-

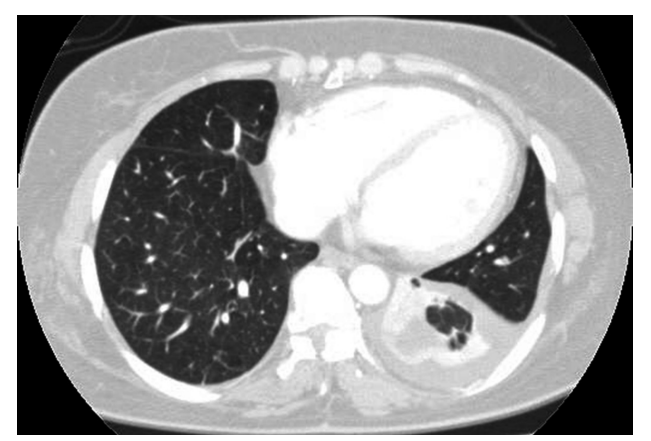

Fig. 1. Chest computed tomography scan showing pleural effusion.

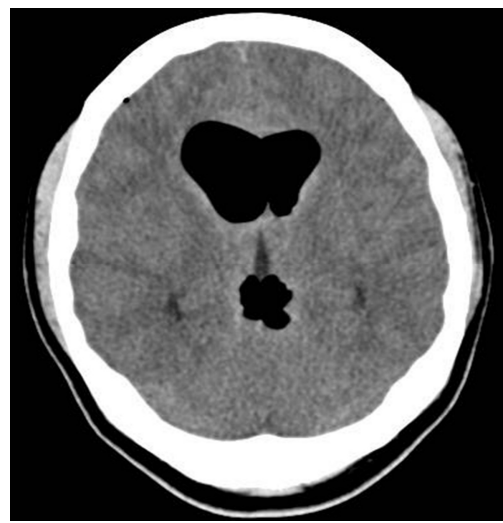

Fig. 2. Brain computed tomography scan after thoracentesis showing pneumocephalus. 
nagement including bed rest with decubitus position was adopted as treatment. Her symptoms improved dramatically. A follow-up brain CT scan after 27 days showed complete resolution of the ventricular and subarachnoid air (Fig. 4). Consecutive chest radiographs showed left-sided pleural effusion, but she had no cough, difficulty in breathing, or sputum. She was discharged and sent home after 7 weeks since admission, and was followed-up in the outpatient department.

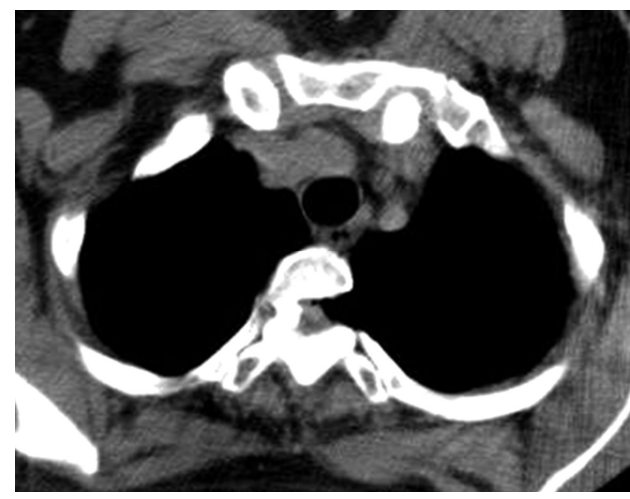

Fig. 3. Chest computed tomography scan after thoracentesis showing air collection in the T2 spinal canal and a fistula.

\section{DISCUSSION}

SAPFs are rare and difficult to diagnose. Only 13 cases of SAPF following surgery have been reported in the literature 1,3,5,6,8,11-14,16-19) (Table 1). Postoperative pneumocephalus could result from combination of a dural tear and a pneumorrhachis. An SAPF may remain asymptomatic when small, or may cause

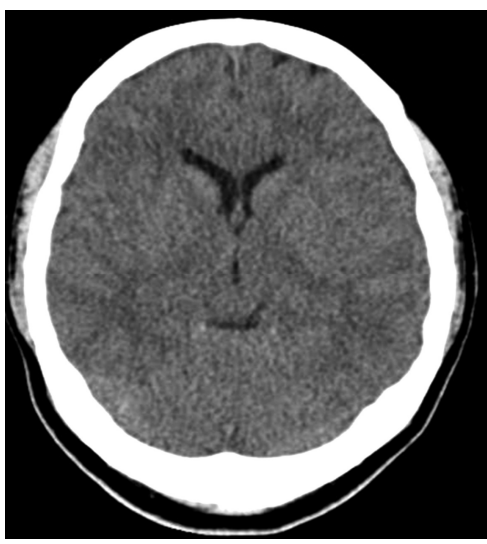

Fig. 4. A follow-up brain computed tomography scan, obtained after 27 days, showing the disappearance of the pneumocephalus.

Table 1. Case of subarachnoid-pelural fistular following surgery

\begin{tabular}{|c|c|c|c|c|c|c|c|}
\hline Authors & $\begin{array}{l}\text { Year } \\
\text { pub. }\end{array}$ & $\begin{array}{l}\text { Age } \\
(\mathrm{yr})\end{array}$ & Sex & Cause & Site & $\begin{array}{l}\text { Duration of } \\
\text { fistula }\end{array}$ & Method of fistula closure \\
\hline $\begin{array}{l}\text { D'Addario } \\
\text { et al. }\end{array}$ & 1974 & 60 & $\mathrm{M}$ & $\begin{array}{l}\text { Open thoracotomy for bronchogenic } \\
\text { carcinoma }\end{array}$ & Right T1-T6 & 3 Days & Thoracostomy tube \\
\hline $\begin{array}{l}\text { Hofstetter } \\
\text { et al. }^{11)}\end{array}$ & 1977 & 43 & $\mathrm{M}$ & $\begin{array}{l}\text { Removal of bronchogenic carcinoma abherent } \\
\text { to vertebral bodies and transverse processs } \\
\text { of right } \mathrm{T} 2 \text { and } \mathrm{T} 3\end{array}$ & $\begin{array}{l}\text { Right T2 } \\
\text { and T3 }\end{array}$ & 2 Months & $\begin{array}{l}\text { Thoracoplasty with removal } \\
\text { of the first four ribs }\end{array}$ \\
\hline Labadie et al. $^{13)}$ & 1977 & 43 & M & $\begin{array}{l}\text { Right upper lobectomy to remove a } \\
\text { squamous cell carcinoma }\end{array}$ & Right T4 & 1 Months & $\begin{array}{l}\text { Thoracoplasty with removal } \\
\text { of the first four ribs }\end{array}$ \\
\hline Frantz et al. ${ }^{8)}$ & 1980 & 64 & $\mathrm{~F}$ & $\begin{array}{l}\text { Traction injury of the intercostal } \\
\text { neurovascular bundle during thoracotomy }\end{array}$ & Left T4 & 6 Days & Thoracostomy tube \\
\hline Katz et al. ${ }^{12)}$ & 1982 & 60 & $\mathrm{~F}$ & Left thoracotomy for removal of mass & Left C7-T1 & 59 Days & $\begin{array}{l}\text { Percutaneous } \\
\text { lumboperitoneal shunt }\end{array}$ \\
\hline $\begin{array}{l}\text { Qureshi } \\
\text { et al. }{ }^{16)}\end{array}$ & 1986 & 56 & $\mathrm{~F}$ & $\begin{array}{l}\text { Surgical removal of a solitary benign nerve } \\
\text { sheath tumor on left side }\end{array}$ & $\begin{array}{l}\text { Left T11 } \\
\text { and T12 }\end{array}$ & 7 Months & Closure with muscle \\
\hline Rice et al. ${ }^{17)}$ & 1987 & 32 & $\mathrm{~F}$ & $\begin{array}{l}\text { Left posterolateral thoracostomy and } \\
\text { decompressive laminectomy }\end{array}$ & Left T6 & 2 Weeks & $\begin{array}{l}\text { Surgical repair and lumbar } \\
\text { subarachnoid drainage }\end{array}$ \\
\hline Trammer $^{19)}$ & 1990 & - & - & Excision of a thoracic ganglioneuroma & Left T4-T5 & - & Closure with muscle \\
\hline $\begin{array}{l}\text { Takenouchi } \\
\text { et al. }\end{array}$ & 1993 & 33 & M & Operation of mediastinal schwannoma & Left T9 & 20 Days & Thoracolumbar drainage \\
\hline Boyev et al. ${ }^{1)}$ & 1995 & 68 & M & $\begin{array}{l}\text { A left upper lobectomy and enbloc } \\
\text { posterior chest wall resection }\end{array}$ & - & - & Thoracostomy tube \\
\hline Díaz et al. ${ }^{5)}$ & 1995 & 49 & $\mathrm{~F}$ & $\begin{array}{l}\text { A lateral extracavitary approach was taken } \\
\text { with a thoracotomy }\end{array}$ & Left T10-T11 & A few days & Surgical repair \\
\hline $\begin{array}{l}\text { Monla-Hassan } \\
\text { et al. }{ }^{14)}\end{array}$ & 1998 & 52 & $\mathrm{~F}$ & T8 to T9 transthoracic diskectomy & Left T8-T9 & 7 Days & Surgical repair \\
\hline $\begin{array}{l}\text { Dickman } \\
\text { et al. }\end{array}$ & 1999 & - & - & $\begin{array}{l}\text { Costotrasversectomy with laminectomy } \\
\text { and facetectomy }\end{array}$ & - & - & Closure with muscle \\
\hline
\end{tabular}


pleural effusion and subsequent dyspnea and pleuritic chest pain, in addition to postural headaches ${ }^{4,5,79)}$, nausea, and vomiting secondary to intracranial hypotension ${ }^{1}$. An SAPF once developed causes a pressure gradient, which allows cerebrospinal fluid (CSF) to flow from the positive-pressure spinal subarachnoid space to the negative-pressure pleural space. The low thoracic pressure created during inspiration causes CSF to flow into the chest cavity, and the high intrathoracic pressure during expiration forces air into the CSF space. This is further complicated by an upright head position that causes an increase in air in the subarachnoid space, resulting in pneumocephalus. The diagnosis of SAPF requires an appropriate clinical setting and relies mostly on the aforementioned symptoms and signs, although imaging modalities are of great value in confirming the presence of the fistula. The commonly used imaging modalities are radionuclide cisternography ${ }^{11)}, \mathrm{CT}$ myelography ${ }^{10)}$, and magnetic resonance imaging. Management of SAPF depends not only on the size of the fistula defect but also on the progression of symptoms, and choosing a treatment strategy is the most challenging part.

Several reports showing that conservative management is available in most of patients, ${ }^{6,18)}$.

In a review of 19 cases of SAPF secondary to trauma, 63\% were treated surgically, $26 \%$ via chest tube drainage or lumbar drainage, and $11 \%$ conservatively ${ }^{15}$. Furthermore, $27 \%$ of the fistulae developing postthoracotomy closed spontaneously ${ }^{2}$. Conservative therapy, which includes bed rest, external lumbar drainage, and chest tube insertion, has been advocated as the initial treatment strategy. Surgical repair of the fistula should be considered after the failure of conservative treatment; however, the appropriate timing for chest tube drainage or surgical intervention remains controversial. Early detection and appropriate therapy will decrease morbidity associated with this rare complication.

\section{CONCLUSION}

Clinicians must be aware of the possibility of SAPF in patients with unilateral pleural effusion who have undergone thoracic spine surgery. Conservative management may be feasible in patients with SAPF, and long-term follow-up is imperative.

\section{CONFLCT OF INTEREST}

No potential conflict of interest relevant to this article was reported.

\section{REFERENCES}

1. Boyev P, Krasna MJ, White CS, McLaughlin JS: Subarachnoidpleural fistula after resection of a pancoast tumor with hyponatremia. Ann Thorac Surg 60:683-685, 1995
2. Brown WM 3rd, Symbas PN: Pneumocephalus complicating routine thoracotomy: symptoms, diagnosis and management. Ann Thorac Surg 59:234-236, 1995

3. D'Addario R, Greenberg J, O'Neill TJ, Spagna P: Pneumocephalus: an unusual cause. J Neurol Neurosurg Psychiatry 37: 271-274, 1974

4. Da Silva VF, Shamji FM, Reid RH, del Carpio-O'Donovan R: Subarachnoid-pleural fistula complicating thoracotomy: case report and review of the literature. Neurosurgery 20:802-805, 1987

5. Díaz P, Maíllo A, Hernández J, Morales F, Jiménez MF, Moreta JA, et al: Subarachnoid-pleural fistula as a complication of the lateral-extracavitary approach to thoracic intraspinal neurinoma. Spine (Phila Pa 1976) 20:1515-1518, 1995

6. Dickman CA, Rosenthal D, Regan JJ: Reoperation for herniated thoracic discs. J Neurosurg 91(2 Suppl):157-162, 1999

7. Fernandez P, Guyot M, Mangione P, Valli N, Basse-Cathalinat B, Ducassou D: Subarachnoid-pleural fistula complicating thoracoscopy: value of In-111 DTPA myeloscintigraphy. Clin Nucl Med 24:985-986, 1999

8. Frantz PT, Battaglini JW: Subarachnoid-pleural fistula: unusual complication of thoracoscopy. J Thorac Cardiovasc Surg 79: 873-875, 1980

9. Godley CD, McCabe CJ, Warren RL, Rosenberg WS: Traumatic subarachnoid-pleural fistula: case report. J Trauma 38:808-811, 1995

10. Hicken P, Martin J, Hakanson S: Computed tomography demonstration of subarachnoid-pleural fistula. Can Assoc Radiol J 41:222-224, 1990

11. Hofstetter KR, Bjelland JC, Patton DD, Woolfenden JM, Henry RE: Detection of bronchopleural-subarachnoid fistula by radionuclide myelography: case report. J Nucl Med 18:981-983, 1997

12. Katz SS, Savitz MH, Osei C, Harris L: Successful treatment by lumboperitoneal shunting of a spinal subclavicular fistula following thoracotomy. Neurosurgery 11:795-796, 1982

13. Labadie EL, Hamilton RH, Lundell DC, Bjelland JC: Hypoliquorreic headache and pneumocephalus caused by thoracosubarachnoid fistula. Neurology 27:993-995, 1997

14. Monla-Hassan J, Eichenhorn M, Spickler E, Talati S, Nockels R, Hyzy R: Duropleural fistula manifested as a large pleural transudate: an unusual complication of transthoracic diskectomy. Chest 114:1786-1789, 1998

15. Pollack II, Pang D, Hall WA. Subarachnoid-pleural and subarachnoid-mediastinal fistulae. Neurosurgery 26:519-525, 1990

16. Qureshi MM, Roble DC, Gindin RA, Scudamore HH: Subarachnoid-pleural fistula. Case report and review of the literature. J Thorac Cardiovasc Surg 91:238-241, 1986

17. Rice TW, Kirsh JC, Schacter IB, Goldberg M: Simultaneous occurrence of chylothorax and subarachnoid pleural fistula after thoracotomy. Can J Surg 30:256-258, 1987

18. Takenouchi N, Miura T, Otake S, Muraki S, Kusaka T, Fujimori $\mathrm{M}$, et al: Cerebrospinal fluid fistula following an operation of mediastinal schwannoma: a case report. Kyobu Geka 46:11521155, 1993

19. Trammer A: Persistent subarachnoid-pleural cerebrospinal fluid fistula following excision of a thoracic ganglioneuroma: case report. Z Kinderchir 45:109-110, 1990 